\title{
Long-Term Side Effects of Mandibular Advancement Devices in Patients with Obstructive Sleep Apnea
}

\author{
Keun Jeong Park, Seong Taek Kim \\ Department of Orofacial Pain \& Oral Medicine, College of Dentistry, Yonsei University, Seoul, Korea \\ 폐쇄성 수면무호흡증 환자에서 장기간 하악전진장치 치료 시 부작용 \\ 박근정, 김성택 \\ 연세대학교 치과대학병원 구강내과
}

Received April 4, 2019

Revised June 14, 2019

Accepted June 21, 2019

Address for correspondence

Seong Taek Kim, DDS, PhD

Department of Orofacial Pain

\& Oral Medicine,

College of Dentistry

Yonsei University,

50-1 Yonsei-ro, Seodaemun-gu,

Seoul 03722, Korea

Tel: $+82-2-2228-8875$

Fax: $+82-2-393-5673$

E-mail: K8756050@yuhs.ac
To evaluate the side effects of long-term mandibular advancement device (MAD) treatment associated with dental and skeletal changes. The search for clinical trials, retrospective studies and systematic review used PubMed with the following Mesh terms: sleep apnea, mandibular advancement device, and long-term. Patients with obstructive sleep apnea in long-term treatment with MAD may experience side effects due to the protruded jaw position. The side effects reported were reduction in overjet, overbite, development of anterior crossbite, posterior openbite, and deteriorations in apnea-hypopnea index severity and treatment efficacy. Also, the use of MAD may lead to the development of temporomandibular disorders in a small number of patients, but these signs are most likely transient. MAD treatment produces time-related dental and skeletal side effects. Since the side effects are progressive, patients in long-term treatment with MAD must be regularly followed up and the device adjusted.

J Sleep Med 2019;16(2):67-70 Malocclusion.

서 론

수면무호흡은 수면 시 반복적으로 상기도가 좁아지면서 코골이, 호흡의 중단, 수면 분절 등을 야기하고, 이는 심박수 의 증가, 혈압 변동, 교감신경계의 활성화로 이어져 심혈관계 질환과 밀접하게 연관성이 있는 것으로 알려져 있다. 이러한 코골이 및 수면무호흡 환자들에 대한 치료법 중 하나인 하악 전방이동장치(mandibular advancement device, MAD)는 무호흡 · 저호흡지수(apnea-hypopnea index, AHI)를 감소 시키고 수면의 질 향상과 주간 졸림증 감소를 통해 삶의 질 을 향상시킬 수 있다. ${ }^{1} \mathrm{MAD}$ 는 양압기(continuous positive airway pressure, CPAP) 치료보다 무호흡 개선의 효과는 더 작거나 가변적인 것으로 알려져 있으나, 혈압 등 심혈관계 기

This is an Open Access article distributed under the terms of the Creative Commons Attribution Non-Commercial License (https://creativecommons.org/licenses/by-nc/4.0) which permits unrestricted non-commercial use, distribution, and reproduction in any medium, provided the original work is properly cited.
능, 삶의 질에 대한 효과는 CPAP과 비슷하다는 연구결과가 증가하고 있다. $\mathrm{MAD}$ 는 경도에서 중등도의 수면무호흡 환자 들에게 추천되며, 심각한 무호흡 환자들 중에도 CPAP에 효 과가 없거나, 불편감으로 인해 $\mathrm{CPAP}$ 에 적응하지 못하는 환 자들에게 치료방법으로 고려될 수 있다. ${ }^{2} \mathrm{MAD}$ 는 수면 시 아 래턱을 전하방으로 내밀게 하여 하악과 혀 기저부의 근육들 을 전방으로 당기고, 늘어지는 연구개와 구개수를 들어올림 으로써 코골이 및 무호흡에 효과가 있는데, 이는 이설골근을 포함한 근육들의 활성도를 바꿈으로써, 장기간 사용 시 환자 의 근골격계에 대한 부작용이 발생할 수 있다.

\section{본 론}

\section{단기간 장착 시 부작용}

$\mathrm{MAD}$ 사용 시 침의 과다 분비, 구강 건조감, 측두하악관절 의 불편감, 치아 통증, 치아의 미세한 이동으로 인한 일시적 
인 교합변화 등이 있으며, 이 중 장치 제거 직후 느껴지는 교 합변화는 일반적으로 12 시간 이내에 회복이 된다. 장치 장착 시 하악의 비습관적인 위치(nonhabitual position)는 구강악 안면계에 영향을 줌으로써 측두하악관절 및 저작근에 증상 을 유발할 수 있으며, 이는 다시 회복될 수 있는 가역적인 증 상이므로 일정 기간의 적응 기간이 필요하다. ${ }^{2-5}$

\section{장기간 장착 시 부작용}

\section{교합 및 골격의 변화}

하악은 전방으로 내미는 장치인 $\mathrm{MAD}$ 를 장기간 장착했을 경우, 단기간 장착 시에는 나타나지 않던 교합과 골격의 변화 들이 관찰된다. 2019년 MAD 사용 환자들에 대해 2년에서 11 년의 추적 기간을 가진 21 개의 연구들을 대상으로 한 체계 적 문헌고찰에 따르면, 장기간의 $\mathrm{MAD}$ 사용은 임상적으로 비가역적인 치과적 부작용을 야기하고, 그중 일부 연구에서 는 지속적인 $\mathrm{MAD}$ 사용 후에 작지만 통계적으로 유의미한 골격적 변화가 나타났다. ${ }^{1}$ 다른 종적인 연구결과에서도 장치 를 장착한 기간이 1 년 이내인 경우에는 교합변화가 임상적으 로 유의미하지 않았지만, 3년 이상 장기간 장착한 경우에는 교합 및 골격에 있어 유의미한 변화가 생기는 것으로 나타났 다. ${ }^{3}$ 이러한 변화에는 대표적으로 수평피개(overjet) 및 수직 피개(overbite)의 감소, 전치부 반대교합(anterior crossbite), 구치부 개교합(posterior openbite), 하악의 총생(crowding) 심 화 등이 있다.

상하악 중절치 절단 간의 수평피개(Overjet) 및 수직피개 (Overbite) 감소

여러 연구들을 통해 장기간 $\mathrm{MAD}$ 장착 시 환자들의 수평 피개와 수직피개가 감소한다고 알려져 있다. 수평피개란 하 악이 습관적 교합 위치에 있을 때 상하악 중절치 절단 간의 수평 거리를 의미하며, 수직피개란 상하악 중절치 절단 간의 수직 거리를 의미한다. 15 년 이상 $\mathrm{MAD}$ 를 사용한 환자 9 명에 대한 연구에서 수평피개와 수직피개가 모두 유의미하게 감 소하였으며, 8년 이상 장치를 사용한 77명의 환자를 대상으 로 한 후향적 연구에서도 장착 기간이 오래될수록 수평피개 와 수직피개가 감소함을 확인할 수 있다. 수평피개의 경우 첫 내원 시와 비교했을 때 평균 $1.9 \mathrm{~mm}( \pm 1.9 \mathrm{~mm})$ 감소하였으 며, 수직피개의 경우 평균 $2.3 \mathrm{~mm}( \pm 1.6 \mathrm{~mm})$ 감소한 것으로 보고되었다. ${ }^{4,6}$ 이때 수직피개는 점차 그 감소량이 줄어드는 추세인 반면, 수평피개의 경우 꾸준히 계속 감소하는 추세를 보였다. ${ }^{6}$ 이는 $\mathrm{MAD}$ 장기간 장착 시 교합 면에서 하악 치아 가 전반적으로 근심(mesial side)으로 움직임으로써 하악 전
치가 전방으로 기울고, 상악전치는 후방으로 기우는 경향에 의해 나타날 수 있다.

전치부 반대교합(Anterior crossbite) 및 구치부 개교합 (Posterior openbite)

장기간 $\mathrm{MAD}$ 를 사용하는 환자들의 경우 수직피개와 수평 피개가 감소하면서 전치부 반대교합이 생기고, 이와 함께 구 치부 교합의 감소가 나타난다. 연구에 따라 구치부 개교합에 대한 기준이 다르기는 하지만 최소 2 개 이상의 구치부 교합이 되지 않는 것을 기준으로 할 때, 8년 이상 MAD 장착 시 $51 \%$ 의 환자(39명/77명)에게서 구치부 개교합이 나타났으며, $62 \%$ 의 환자(48명/77명)에게서 평균 4 개의 전치 반대교합이 나타 났다. ${ }^{6} \mathrm{MAD}$ 를 사용하는 167 명의 환자들에게서 나타나는 구 치부 개교합의 유병률과 발생률을 장치 장착 전, 장치 장착 118 일째, 208일째, 413일째 내원 시마다 조사한 결과 평균 $6.1 \%$ 의 구치부 개교합 발생률을 보였으며, 유병률의 경우 시 간이 지날수록 증가하여 장치 장착 기간이 413일 되었을 때 $17.9 \%$ 의 유병률을 보였다. ${ }^{5}$ 반면 환자들을 대상으로 설문조 사를 통해 교합변화의 정도와 지속 시간에 대해 조사한 결과, 실제 구치부 개교합이 발생한 환자들 중 $28.6 \%$ 의 환자들만 이 교합변화로 인한 불편감을 인지했다. ${ }^{5}$ 이는 실제로 구치부 개교합이 발생하였음에도 불구하고 환자들이 실제로 인지하 지 못하는 경우가 많다는 것을 의미하며, 증상의 악화를 예 방하기 위해 환자의 주기적인 내원을 통해 교합을 확인하고 필요 시 장치 장착을 중단하거나 장착 시간을 조절할 필요가 있다. 그 외에도 장치를 장착하는 기간이 길어질수록 하악 전 치부의 총생이 심해지는 경향이 있으며, 이와 더불어 하악궁 에서 견치 간 거리 및 구치 간 거리가 유의미하게 넓어진다. ${ }^{6}$

\section{측두하악관절장애}

$\mathrm{MAD}$ 장착 시 기상 후 일시적으로 턱관절 및 저작근의 불 편감이 나타날 수 있는데, 이는 비습관적인 위치로 하악을 내 민 상태에서 수 시간 동안 유지 시 저작근과 인대에 대한 부 하로 인해 발생한다. 수면무호흡 환자들 중 $\mathrm{MAD}$ 를 사용하 는 환자들이 CPAP을 사용하는 환자들에 비해 치료 전보다 치료 2 달 경과 후 측두하악관절장애 발생률이 더 큰 것으로 나타났으며, 특히 근막통증, 관절통 등 통증이 동반된 측두하 악관절장애가 크게 증가하는 것으로 나타났다. ${ }^{7}$ 하지만 이러 한 증상들은 대체로 장치 장착 초반에는 증가하지만 시간이 지날수록 점차 감소하는 경향을 보이며, $\mathrm{MAD}$ 를 장착하는 167 명 환자의 측두하악관절장애 발생에 대한 연구에 따르 면, ${ }^{5}$ 첫 내원 시보다 장치 장착 후 413 일이 지났을 때 오히려 측두하악관절장애의 발생이 감소하는 것으로 나타났다. 특 
히 관절음의 경우 초진 시에는 167 명 중 18 명의 환자에게서 발생하여 $10.8 \%$ 의 유병률을 보였으나, 내원 시마다 점차 감 소하여 MAD 장착 후 413 일이 지난 다음에는 85 명 중 5명의 환자만이 관절음이 있는 것으로 보고되어 $5.9 \%$ 의 유병률을 보였다. ${ }^{5}$ 장기간 통증이 지속되거나 개폐구 시 관절음이 발생 되는 경우 주로 하악의 전방 이동 정도가 큰 경우 흔히 발생 하며, 장치의 두께가 지나치게 두꺼운 경우에는 경부 및 후 두부에 불편감을 유발하기도 하므로 하악의 전방 이동량을 조절하거나 장치 두께를 줄임으로써 완화시킬 수 있다. ${ }^{8}$ 오 히려 장치 치료 전 원래 턱관절 및 저작근 증상이 있었던 환 자들 중 일부는 장치 치료 후 증상이 소실된 경우도 있는데, 이는 $\mathrm{MAD}$ 가 근육에 대한 치료 효과가 있으며, 교합장치만 큼 이갈이와 같은 야간의 이상 기능 활동으로부터 유발되는 부정적인 영향을 감소시킬 수 있기 때문이다. 실제로 $\mathrm{MAD}$ 를 3년 이상 장착한 환자들을 대상으로 한 연구결과, 측두하 악관절에서 발생하는 관절음(clicking or popping)의 변화가 나타나기는 했지만 콘빔전산화단층촬영(cone beam computed tomography)상 골 표면의 유의미한 변화는 없었으며, 이는 측두하악관절장애가 $\mathrm{MAD}$ 치료에 있어 금기증은 아님 을 시사한다. ${ }^{3}$

\section{무호흡에 대한 효과 감소}

$\mathrm{MAD}$ 를 사용한 수면무호흡 치료를 받은 환자들의 경우 초 반에는 $\mathrm{AHI}$ 가 낮아지는 등 효과가 있던 환자들도, 이를 장기 간 장착하는 경우에는 그 효과가 감소할 수 있다. Marklund 등에 의한 연구에 따르면 15년 이상 $\mathrm{MAD}$ 를 사용한 환자들 의 경우, 장치를 장착했을 때와 장착하지 않았을 때의 $\mathrm{AHI}$ 가 이전보다 모두 증가하는 양상을 보고하였다. ${ }^{4}$ 이는 장기간 장치 장착 시 위에서 언급한 상하악 전치부 간 수평피개 감소 등의 교합변화 가능성이 높아짐에 따라, 장치에 의한 하악의 전방 이동량이 처음보다 상대적으로 감소하여 발생할 수 있 다. 이는 하악의 전방 이동량이 일정하게 고정되어 있는 경우 발생하기 쉬우므로, 최근에는 환자의 무호흡 증상에 따라 전 방 이동량을 바꿀 수 있는 장치가 주로 사용되고 있다.

\section{고 찰}

코골이 및 무호흡 환자들에게 있어서 구강 내 장치 치료는 $\mathrm{CPAP}$ 을 대체하여 고려될 수 있는 방법이다. 장기간으로 $\mathrm{MAD}$ 를 장착한 환자들의 경우 나타날 수 있는 부작용들에 대해 정확히 인지하고 주기적으로 확인한다면, 영구적인 부 작용의 가능성을 감소시킬 수 있을 것이다. 이와 더불어 장치 로 인한 부작용을 증가시키는 기여 요인에 대한 연구 및 고찰
이 필요하다. 코골이 및 수면무호흡 환자들 중 장기간 $\mathrm{MAD}$ 를 장착한 환자들의 교합변화에 대한 연구결과, 기존에 $\mathrm{AHI}$ 가 높았던 환자들의 경우 수평피개의 감소가 더 큰 것으로 나 타났으며, 수평피개가 큰 환자일수록 수평피개와 수직피개의 변화가 더 큰 것으로 나타났다. 수직피개가 큰 환자의 경우 전치부 반대교합이 덜한 것으로 나타났으나, 수직피개의 변 화는 더 큰 것으로 나타났다. ${ }^{6}$ 이를 통해 장기간 장치 장착 시 에 나타나는 교합변화의 기여 요인으로 치료 전 환자의 $\mathrm{AHI}$, 수평피개 및 수직피개 등이 영향을 줄 수 있음을 알 수 있다. 이처럼 치료 전 환자의 증상 및 상태에 따른 장치 치료 가능 성과 환자의 위험요인에 의해 나타날 수 있는 부작용 가능성 에 대해 우선적으로 고려할 필요가 있으며, 이를 위해 2015년 미국수면학회에서 발행한 수면무호흡증 및 코골이에 대한 구강 내 장치 치료 가이드라인에 제시된 내용과 구강 내 장 치 치료와 관련된 부작용을 확인하고 이의 발생을 감소시키 기 위하여 치과의사에 의한 정기 검진이 필요하다. ${ }^{9}$ 이에 대 한 연구 및 고찰이 이루어진다면, 장기간 $\mathrm{MAD}$ 치료가 고려 되는 환자들에 대해 임상적으로 교합변화 가능성이 높은 위 험군을 예측하여 치료방법 및 추적 기간 결정 시 도움이 될 것으로 판단된다.

\section{Conflicts of Interest}

The authors have no potential conflicts of interest to disclose.

\section{Acknowledgments}

None.

\section{ORCID iDs}

Keun Jeong Park https://orcid.org/0000-0003-4559-9398

Seong Taek Kim https://orcid.org/0000-0001-9506-5103

\section{Author Contributions}

Conceptualization: Seong Taek Kim, Keun Jeong Park. Methodology: Seong Taek Kim. Supervision: Seong Taek Kim. Writing_original draft: Keun Jeong Park. Writing_-review \& editing: Seong Taek Kim.

\section{REFERENCES}

1. Bartolucci ML, Bortolotti F, Martina S, Corazza G, Michelotti A, Alessandri-Bonetti G. Dental and skeletal long-term side effects of mandibular advancement devices in obstructive sleep apnea patients: a systematic review with meta-regression analysis. Eur J Orthod 2019;41:89100 .

2. Marklund M, Verbraecken J, Randerath W. Non-CPAP therapies in obstructive sleep apnoea: mandibular advancement device therapy. Eur Respir J 2012;39:1241-1247.

3. Knappe SW, Bakke M, Svanholt P, Petersson A, Sonnesen L. Longterm side effects on the temporomandibular joints and oro-facial function in patients with obstructive sleep apnoea treated with a mandibular advancement device. J Oral Rehabil 2017;44:354-362.

4. Marklund M. Long-term efficacy of an oral appliance in early treated patients with obstructive sleep apnea. Sleep Breath 2016;20:689-694.

5. Perez CV, de Leeuw R, Okeson JP, et al. The incidence and prevalence 
of temporomandibular disorders and posterior open bite in patients receiving mandibular advancement device therapy for obstructive sleep apnea. Sleep Breath 2013;17:323-332.

6. Pliska BT, Nam H, Chen H, Lowe AA, Almeida FR. Obstructive sleep apnea and mandibular advancement splints: occlusal effects and progression of changes associated with a decade of treatment. J Clin Sleep Med 2014;10:1285-1291.

7. Doff MHJ, Veldhuis SKB, Hoekema A, et al. Long-term oral appliance therapy in obstructive sleep apnea syndrome: a controlled study on temporomandibular side effects. Clin Oral Investig 2012;16:689-697.

8. Mehta NR, Correa LP. Oral appliance therapy and temporomandibular disorders. Sleep Med Clin 2018;13:513-519.

9. Ramar K, Dort LC, Katz SG, et al. Clinical practice guideline for the treatment of obstructive sleep apnea and snoring with oral appliance therapy: an update for 2015. J Clin Sleep Med 2015;11:773-827. 